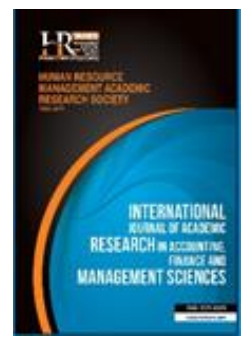

International Journal of Academic Research in Accounting, Finance and Management Sciences

Vol. 8, No.2, April 2018, pp. 102-112

E-ISSN: 2225-8329, P-ISSN: 2308-0337

(c) 2018 HRMARS

www.hrmars.com

To cite this article: Anghel M.-G., Anghelache C., Dumitrescu, D., Burea D., Stoica, R. (2018). Analysis of the Effect of Accessing the Community Funds for Financing Investments on Romania's Economic Growth, International Journal of Academic Research in Accounting, Finance and Management Sciences 8 (2): 102-112.

\title{
Analysis of the Effect of Accessing the Community Funds for Financing Investments on Romania's Economic Growth
}

\author{
Mădălina-Gabriela ANGHEL ${ }^{1}$, Constantin ANGHELACHE ${ }^{2}$, \\ Daniel DUMITRESCU ${ }^{3}$, Doina BUREA ${ }^{4}$, Radu STOICA ${ }^{5}$ \\ ${ }^{1}$,Artifex" University of Bucharest, Romania, ${ }^{1}$ E-mail: madalinagabriela anghel@yahoo.com \\ ${ }^{2}$ Bucharest University of Economic Studies/„Artifex” University of Bucharest, Romania, ${ }^{2}$ E-mail: actincon@yahoo.com \\ ${ }^{3}$ European Center for Services Investments and Financing, Romania, ${ }^{3} E$-mail: danidumitrescu@yahoo.com \\ ${ }^{4,5}$ Bucharest University of Economic Studies, Romania, \\ ${ }^{4}$ E-mail: doina.burea@yahoo.com, ${ }^{5}$ E-mail: radustoica68@yahoo.com
}

\begin{abstract}
The development and growth of a country, whether or not a member of the European Union, depends on its investment capacity. Thus, we can discuss how Romania has used the Multi-Annual Financial Framework offered by the European Union to fully fund the new Member States of the Union. The authors focus on the representation of Romania's first Multilateral Financial Framework 2007-2013 and the first half of the second one (2014-2020). Issues related to accessing the European funds, the share of European funds in the annual Gross National Product (GDP) achieved. Based on several indicators, we present a comparative analysis of how the Multi-Annual Financial Framework 2007-2013 was used and the first years of the second Financial Framework of the European Union by Romania and other European Union states. In the following, reference is made to the impact of European investment projects involving Romania on GDP growth. The extent to which Community funds are absorbed in the operational programs is also presented. The analysis is extended to the contracting stage on the three types of funds and the effect on the financing of small and medium enterprises in Romania.
\end{abstract}

Key words Financing, Economic Research, Investment, Economic Growth, European Union, Community Funds

Received: 15 May 2018 (C) The Authors 2018

Revised: 30 May 2018 Published by Human Resource Management Academic Research Society (www.hrmars.com)

Accepted: 06 Jun 2018 This article is published under the Creative Commons Attribution (CC BY 4.0) license. Anyone may reproduce, distribute, translate and create derivative works of this article (for both commercial and noncommercial purposes), subject to full attribution to the original publication and authors. The full terms of this license may be seen at: http://creativecommons.org/licences/by/4.0/legalcode

\section{Introduction}

In this article, the authors have focused and deepened the analysis of technical-scientific cooperation and project funding within the European Union. Romania's accession documents to the European Union have provided for a series of measures that will lead to the adjustment of the national economy according to the high standards of the European Union. From this point of view Romania has received some grace periods up to the alignment with the standards imposed by the European Union. The role of the European Union was to ensure a broad framework for cooperation among member countries so that the projects achieved could deliver positive results that would drive economic growth for each Member State. ived some grace periods up to the alignment with the standards imposed by the European Union.

There are enough projects within the European Union, all of which can be considered in the individual evolutions of each country, but also the whole of the European Union. Romania, like the other countries that joined the European Union after 2005, still faces some problems regarding the alignment 
with the standards imposed by the European Union. From this point of view, in this article, the authors focus on those difficulties, suggesting that measures should be taken to standardize the national economy to those of the European Union as set out in directives clearly adopted by the European Union. In the presented context, it is of particular importance how Romania and other countries that joined the last wave after 2005 use the Multianula Financial Framework launched in 2007 by the European Union to ensure an optimal level of funding for this group of states. The authors carry out a careful analysis of how Romania has used the EU funding framework. There are presented tables and diagrams showing the stage of implementation in Romania of the financing framework, access to European funds, the level of use in projects, the access of small and medium enterprises to the financing within the "mentioned" framework, etc. Concluding references are also made to the effect of the benefits of the Financial Framework on the growth of the Gross Domestic Product in Romania and other states in the group "the last countries that have joined the European Union".

The authors analyze the role of investment financing, allocations from the Community budget through the Multi-Annual Financing Framework and other funded funds.

\section{Literature review}

Akçomaka and ter Weel (2009) demonstrated that higher innovation performance contributes to raising per capita income and that social capital indirectly affects this growth by encouraging innovation. Anghel, Anghelache and Dumitrescu (2016) addressed a number of issues related to some proposed financial measures to support innovative small and medium-sized enterprises. Anghelache, Anghel et al (2016) analyzed the main methods and models that can be applied for the absorption of community funds. Berezin and Diez-Medrano (2008) studied elements of political legitimacy and popular support for European integration. Chalmers (2013) analyzed the information factors of the interest group's access to the European Union in terms of supply. Dachs and Pyka (2010) examined the current internationalization of innovation activities and identifies key determinants for the countries of the European Union. Farole, Rodríguez-Pose and Storper (2011) addressed aspects of cohesion policy in the European Union. Goldberg and Pavcnik (2007) discussed how globalization has affected income inequality in developing countries. Kennan (2017) investigated the implications for the labor market of allowing free cross-border migration, with particular reference to the EU. Lane (2006) tried to identify how the European Monetary Union influenced the degree of economic union between member countries. Maggioni, Nosvelli and Uberti (2007) studied two relational knowledge-based phenomena, namely participation in the same research networks and EPO co-patent applications. Onetti, Zucchella, Jones and McDougall-Covin presented how new technology-based companies are affected by globalization in terms of innovation pace and competitive pressure. Pinto (2009) proposed a typology of regional innovation profiles to understand the diversity of innovation in the European Union. Pulignano (2009) discussed international cooperation in the field of virtual networks in Europe. Voigt and Moncada-Paternò-Castello (2012) analyzed how the composition of the sector and the scale of R \& D investment in the EU will differ from 2020 in the past if it is assumed that a selection of SMEs investing in research and development development is on a rapid growth step.

\section{Research methodology and data. Results and discussions}

Currently, we are at the middle of the Multilateral Financial Framework 2014-2020. The MFF 2007 2013 was the first full funding period for the new Member States of the European Union and the results are currently quantifiable and can partially compare the evolution of the two programming periods. These sources of funding have made a significant contribution to the development of the new Gross Domestic Product, intervening on several issues such as transport infrastructure, environmental projects, two areas that have lagged behind in the region in recent years. European funds have also been used in the rehabilitation of historical sites, cultural and heritage sites, the modernization of urban areas, the extension of the urban utilities infrastructure. Another important aspect was the development of human resources through the active involvement of the population in the labor market, the development of associations and foundations. On the ICT side, public authorities have implemented many e-government solutions or investments in the ICT infrastructure. 
It should be noted that this multiannual financial framework 2007-13 took place in parallel with the global financial and economic crisis, which had two effects: one of them is to realize that they are an important and viable source of funding if properly used and fully absorbed may have beneficial effects on GDP growth especially in the context of the economic and financial crisis. The second is related to the cofinancing needed to access and implement European projects, meaning that states that have provided public tools to facilitate co-financing were more likely to absorb these funding altogether.

As a common feature of European funds management in Central and Eastern Europe over the period 2007-2012, it can be noticed that in most Member States the contracting of European funds started only in 2008 and the actual reimbursement of the funds was delayed for a year or two. This state of affairs is caused by the lack of experience of the new Member States, the poor organization and, in some cases, the lack of national or private co-financing.

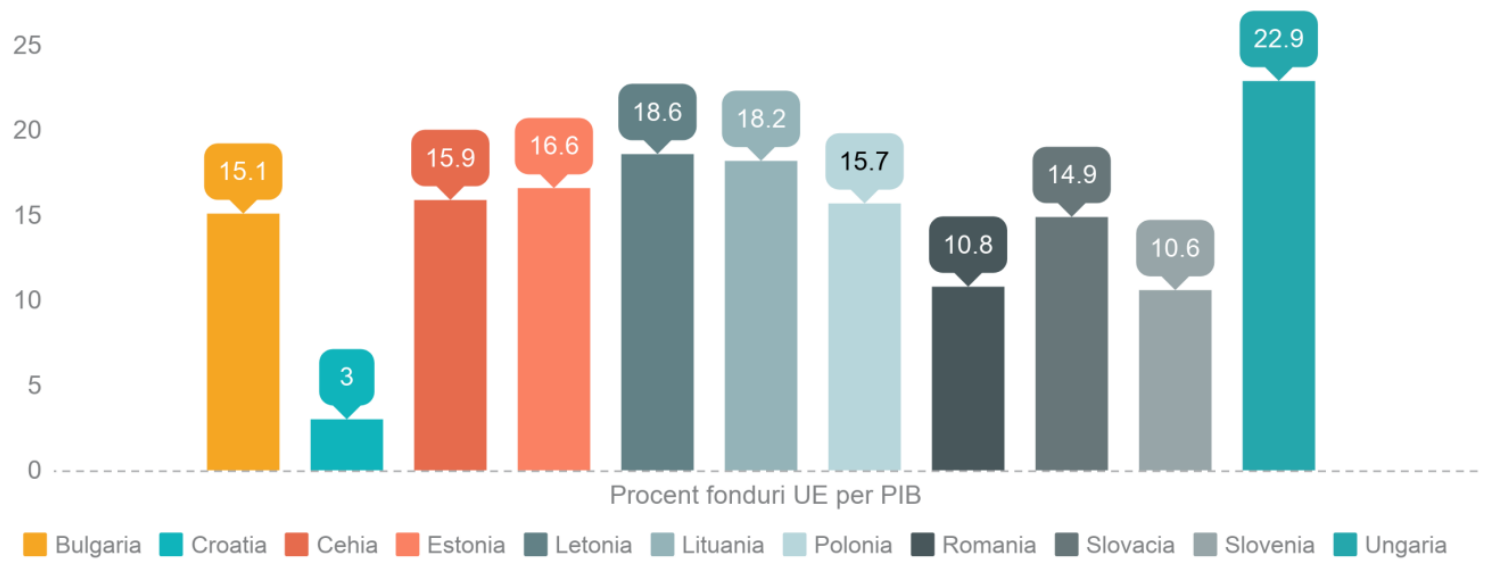

Data source: Eurostat; data is processed by the authors

Figure 1. Percent European Funds/GDP 2007 - 2015

Compared to the new 2014-2020 period, Research - Development - Innovation did not have a significant allocation of funds in this region. Most of the funds were aimed at improving living standards and raising living standards so as to reach the EU27 average. Thus, the latest statistics show that European funds accounted for between 10 and $25 \%$ of annual GDP, which had positive effects for the European Cohesion Policy. Thus, in the case of Hungary, European funds had the largest share, namely $23 \%$ of GDP, followed by Latvia by about $19 \%$, Lithuania by $18 \%$, the Czech Republic by $16 \%$ and Poland by $16 \%$. Romania, Slovenia was at the end of the ranking by $10.8 \%$ and $10.6 \%$, the lowest percentage being Croatia with only $3 \%$.

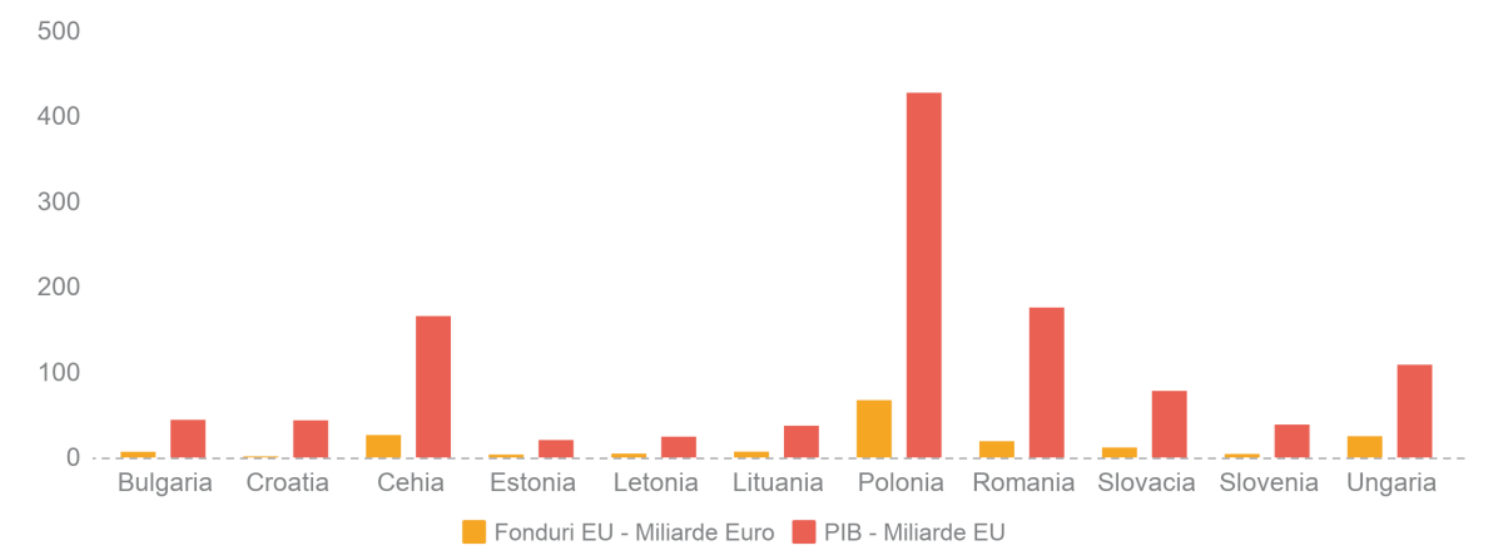

Data source: Eurostat; data is processed by the authors

Figure 2. European funds/GDP $2007-2015$ 
Taking the year of integration into the European Union in 2007, European co-financing was a key element for the GDP growth of the following Central and Eastern European countries (Bulgaria, the Czech Republic, Croatia, Estonia, Latvia, Lithuania, Poland, Romania , Hungary, Slovenia, Slovakia). In particular, the Czech Republic, Estonia, Hungary, Latvia, Lithuania, Poland, Slovenia and Slovakia joined the EU on 1 May 2004; Bulgaria and Romania on 1.01.2007, and Croatia on 1.07.2013. Overall, over the period 2007-13, these countries had a cumulated budget of 175 billion Eur, with national and private co-financing amounting to an average of $15.5 \%$ of national GDP.

Table 1. Statistical data Multi - annual financial framework MFF 2007 - 2013 ECE

\begin{tabular}{|l|c|c|c|c|c|c|}
\hline $\begin{array}{c}\text { Member State } \\
\text { of the ECE }\end{array}$ & $\begin{array}{c}\text { Population } \\
\text { (million) }\end{array}$ & $\begin{array}{c}\text { GDP Billion } \\
\text { Eur }\end{array}$ & $\begin{array}{c}\text { GDP per } \\
\text { capita Eur }\end{array}$ & $\begin{array}{c}\text { EU funds 2007 } \\
-2013 \text { Billion } \\
\text { Eur }\end{array}$ & $\begin{array}{c}\text { EU Funds per } \\
\text { capita Eur }\end{array}$ & $\begin{array}{c}\text { EU funds per } \\
\text { GDP\% } \\
\text { Eur }\end{array}$ \\
\hline Bulgaria & 7,2 & 42,00 & 5833 & 6,67 & 927 & $15,9 \%$ \\
\hline Croatia & 4,24 & 42,96 & 10129 & 1,27 & 299 & $3 \%$ \\
\hline Czech Republic & 10,51 & 154,94 & 14700 & 26,30 & 2502 & $17 \%$ \\
\hline Estonia & 1,32 & 19,53 & 14849 & 3,40 & 2588 & $17,4 \%$ \\
\hline Hungary & 9,88 & 103,00 & 10458 & 24,92 & 2523 & $24,1 \%$ \\
\hline Latvia & 1,99 & 24,06 & 12099 & 4,53 & 2278 & $18,8 \%$ \\
\hline Lithuania & 2,94 & 36,29 & 12329 & 6,78 & 2302 & $18,7 \%$ \\
\hline Poland & 38,48 & 403,08 & 10474 & 67,19 & 1746 & $16,7 \%$ \\
\hline Romania & 19,95 & 150,66 & 7553 & 19,18 & 961 & $12,7 \%$ \\
\hline Slovakia & 5,42 & 75,21 & 13875 & 11,65 & 2149 & $15,5 \%$ \\
\hline Slovenia & 2,06 & 37,25 & 18067 & 4,10 & 1989 & $11 \%$ \\
\hline
\end{tabular}

Data source: Eurostat and national databases; data is processed by the authors

Among the countries presented in the table above, Poland obtained the largest European funds budget, being the largest in terms of population. Together with the Czech Republic, Poland accounts for more than $50 \%$ of the total European funds allocated to this region.

The budget for the Multi-Annual Financial Framework 2007 - 2013 has had different implementation and absorption outcomes according to the analyzed Member States. Thus, in all 11 new Member States, 180 billion Eur of financing contracts were signed, almost 5\% more than the allocated budget. During 2015, approximately $80 \%$ of the budget related to these contracts was transferred to the beneficiaries.

According to the European money spent $(n+2)$ rule, in the 9 years of implementation, the 10 Central and Eastern European countries (not calculating Croatia) contracted nearly 107\% of the $2007-13$ budget. , Bulgaria, Slovakia and Hungary had the highest percentage of contracting, between $110 \%$ and $120 \%$, and the Czech and Estonian rankings were $92 \%$ and $95 \%$, respectively. Contrary to the degree of contracting, the degree of reimbursement of European funds to the final beneficiary differed a lot from the aforementioned ranking. As can also be seen from the table below, Lithuania and Estonia paid around $90 \%$ and $91 \%$, while Slovakia and Romania paid $70 \%$ and 50\% repayments in 2015 respectively.

Table 2. Implementation of the MFF 2007 - 2013 ECE by 2015

\begin{tabular}{|l|c|c|c|c|c|}
\hline $\begin{array}{c}\text { Member State } \\
\text { ECE }\end{array}$ & $\begin{array}{c}\text { Budget 2007 - } \\
\mathbf{2 0 1 3} \text { billion Eur }\end{array}$ & $\begin{array}{c}\text { Budget 2007 - } \\
\mathbf{2 0 1 3} \text { per } \\
\text { capita Eur }\end{array}$ & $\begin{array}{c}\text { Amount } \\
\text { contracted billions } \\
\text { of Eur }\end{array}$ & $\begin{array}{c}\text { Percentage of } \\
\text { contracting \% }\end{array}$ & $\begin{array}{c}\text { Percentage of } \\
\text { payments } \\
\text { (absorption) \% }\end{array}$ \\
\hline Bulgaria & 6,674 & 927 & 7,7 & $105 \%$ & $95 \%$ \\
\hline Czech Republic & 26,303 & 2502 & 25,2 & $103 \%$ & $89 \%$ \\
\hline Estonia & 3,403 & 2588 & 3,3 & $100 \%$ & $95 \%$ \\
\hline Hungary & 24,921 & 2523 & 28 & $117 \%$ & $111 \%$ \\
\hline Latvia & 4,530 & 2278 & 4,8 & $104 \%$ & $97 \%$ \\
\hline Lithuania & 6,775 & 2301 & 6,8 & $99 \%$ & $99 \%$ \\
\hline
\end{tabular}




\begin{tabular}{|l|c|c|c|c|c|}
\hline $\begin{array}{c}\text { Member State } \\
\text { ECE }\end{array}$ & $\begin{array}{c}\text { Budget 2007 - } \\
\text { 2013 billion Eur }\end{array}$ & $\begin{array}{c}\text { Budget 2007 - } \\
\text { 2013 per } \\
\text { capita Eur }\end{array}$ & $\begin{array}{c}\text { Amount } \\
\text { contracted billions } \\
\text { of Eur }\end{array}$ & $\begin{array}{c}\text { Percentage of } \\
\text { contracting \% }\end{array}$ & $\begin{array}{c}\text { Percentage of } \\
\text { payments } \\
\text { (absorption) \% }\end{array}$ \\
\hline Poland & 67,186 & 1745 & 68,2 & $100 \%$ & $92 \%$ \\
\hline Romania & 19,175 & 961 & 20,3 & $116 \%$ & $73 \%$ \\
\hline Slovakia & 11,651 & 2149 & 13,1 & $122 \%$ & $97 \%$ \\
\hline Slovenia & 4,101 & 1989 & 4,3 & $107 \%$ & $105 \%$ \\
\hline
\end{tabular}

Data taken from Eurostat and national databases and processed by authors

The difference between the degree of contracting and the degree of repayment or absorption of European funds by the final beneficiary is a good indicator of the effectiveness of the management of European funds in each Member State. Estonia, Lithuania and Latvia and Slovenia have the smallest difference between contracting and absorption rates, and at the top of the list we find Bulgaria, Slovakia and Romania. The data in the table above is shown graphically in the figure 3.

150

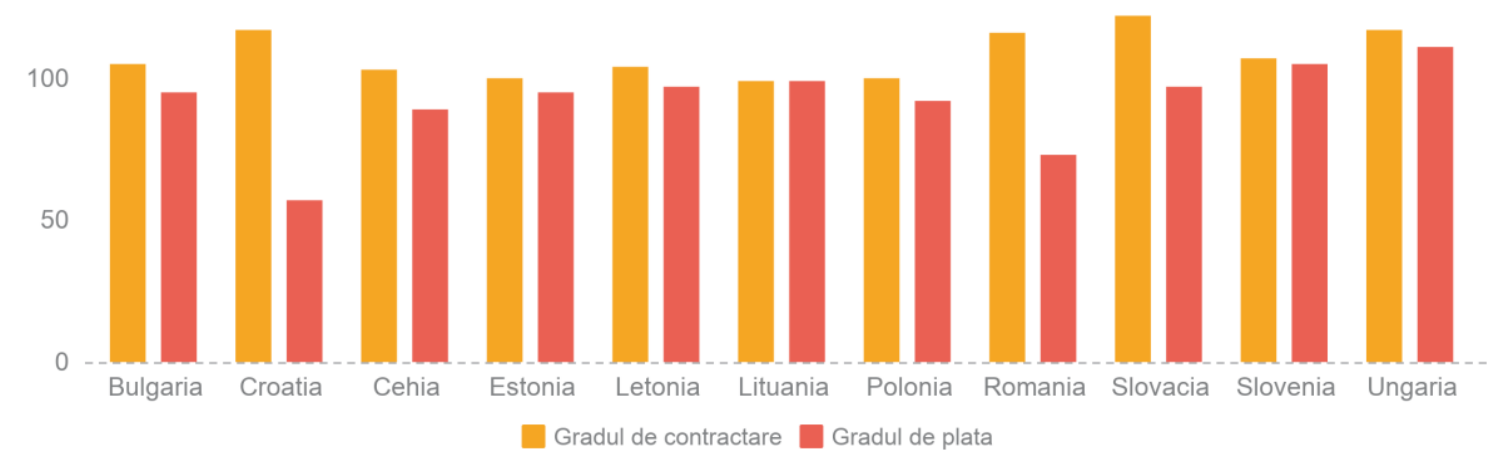

Data source: Eurostat; data is processed by the authors

Figure 3. The difference between the degree of contracting and the repayment rate of the MFF $2007-2013$

For the period 2014-2020, Poland will have the largest budget allocated from the Central and Eastern European countries with EUR 76.87 billion, followed by Romania with EUR 22.54 billion and Hungary with EUR 21.50 billion. The Czech Republic will receive a budget of 21.63 billion Eur, Slovenia 3, 26 billion, Slovakia 13.77 billion. The lowest amounts will be allocated to Croatia, 8.4 billion, Bulgaria 7.37 billion, Lithuania 6.71 to Latvia 4.39 billion and 3.3 billion Estonia.

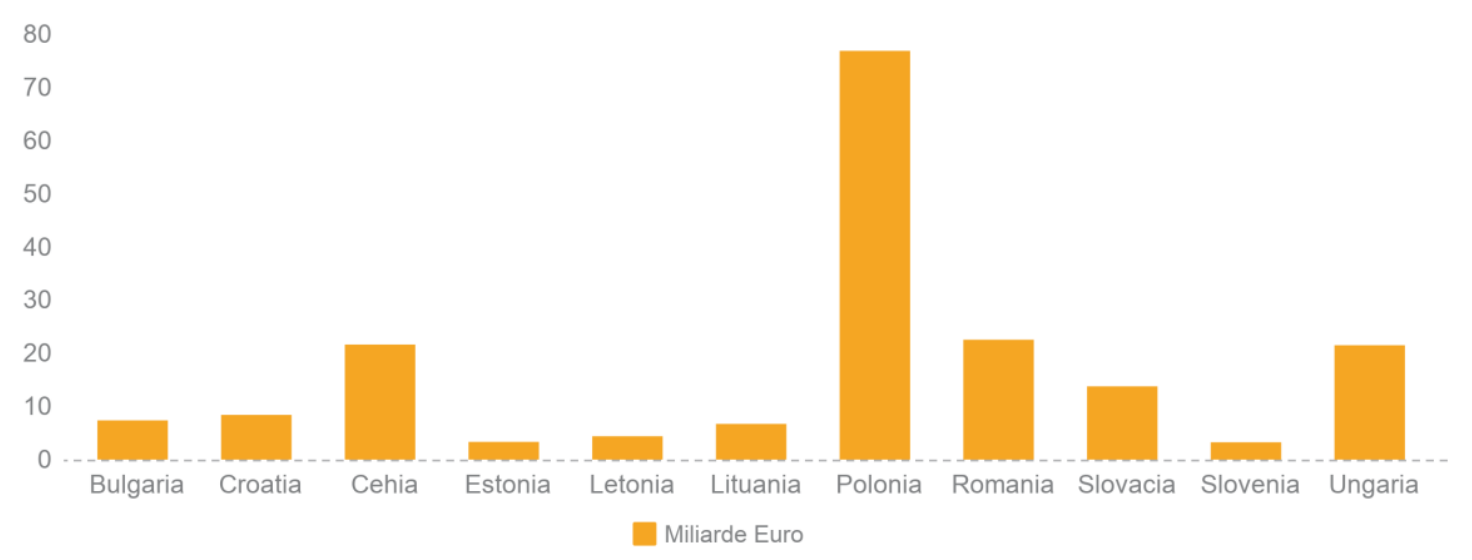

Data source: European Commission, data processed by authors

Figure 4. Budget Multi-Annual Financial Framework 2014-2020 broken down into Central and Eastern European countries 
Currently, the official data of the first three years of the 2014-2020 multiannual financial framework can be analyzed and compared with the outcomes of the years 2007-2009. What is important to highlight is that for this region of the EU, European funds still represent a important segment of public funding. Thus, from the comparative analysis of these two periods, it can be noticed that the late launch of the ESIF programs delayed the start of the operational programs in the countries of Central and Eastern Europe. One reason is the channeling of government efforts to finalize the previous programming in the best possible conditions. Thus, according to the $n+2$ rule, until 2015 and with derogation until 2016, beneficiary countries of European funds could complete the procedure for spending European funds and settlements with the EU.

In the first three years of the new funding period, 2014-2016, Central and Eastern European countries show different performances as follows:

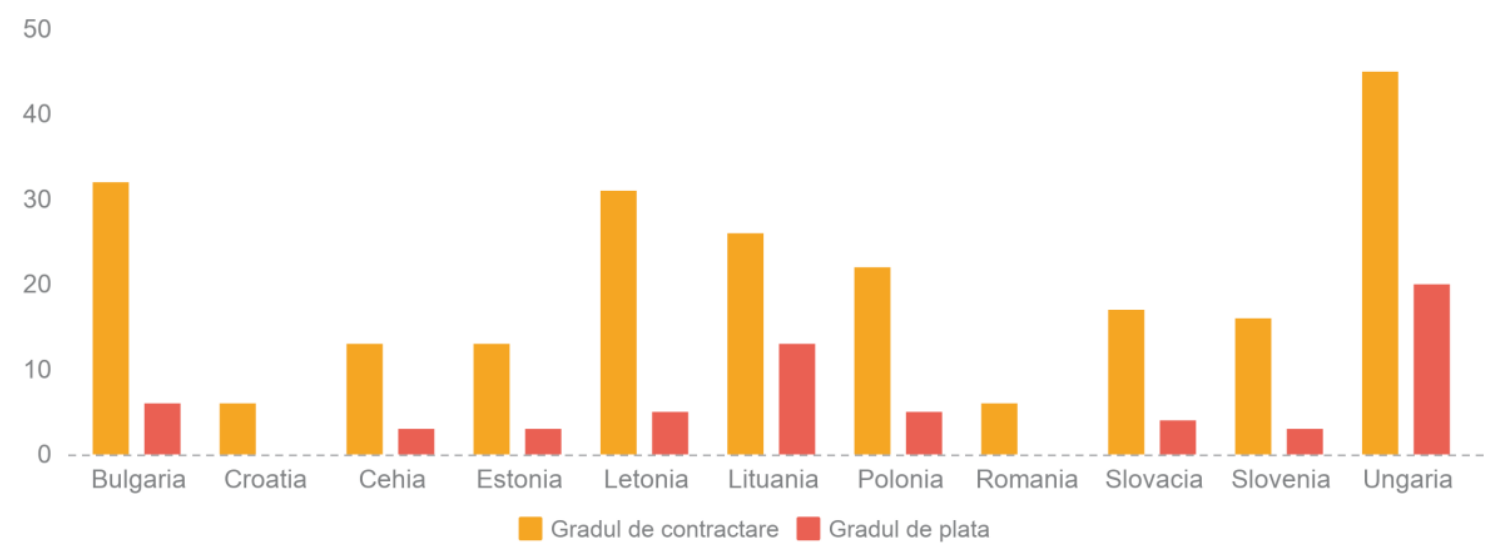

Data source: Eurostat and European funds ministry, data processed by authors

Figure 5. The difference between the contracting rate and the reimbursement rate 2014-2016

\section{The impact of European investment projects on GDP growth in Romania}

The allocation of European Structural and Cohesion Funds for Romania over the period 2007-2013 was $€ 19.2$ billion and co-financing $€ 4.5$ billion. The absorption rate of European funds for the programming period 2007 - 2013 (2015) was at the level of 73\%. Unfortunately, Romania ranks last with a $43 \%$ difference between the contracting rate and the absorption rate (being overtaken only by Croatia, the country that joined the EU much later). The comparison of the absorption rate in Central and Eastern Europe shows that Romania was at the end of 2015 last. The group's performance was Lithuania, Latvia and Estonia, which surpassed Poland's previous performance, which has undergone certain corrections due to the unlawfulness of certain public procurement. Among the measures taken by leading countries in absorption, we can list the budget allocations for co-financing and pre-financing (both for SMEs and for public authorities), special programs for less developed areas.

In Romania, among the causes that led to the lowest absorption rate, we mention the unfavorable macroeconomic context and legislative barriers. As can be seen from Table 1.3 below, the macroeconomic context stood between 2009 and 2015 in the wake of the economic and financial crisis that led to the decline of the Gross Domestic Product in the early years. Budgetary policies taken over from 2009 to 2011 have been some restrictive, cumulated with VAT increases, the depreciation of the national currency and the tightening of credit conditions have had negative effects on the entire macroeconomic context. As legislative barriers, we mention the absence of coherent national strategies, the exaggerated number of opinions from other institutions, restrictions on staff hiring, blurring in the procurement process, the lack of rules on the application of certain laws.

Also, for Romania, almost all operational programs were launched with a long delay at the end of 2008 and 2009 respectively. delays in the implementation process. Issues have also arisen in the case of beneficiaries in terms of the public procurement process, little respected by the latter, and lack of experience in the management of European projects. 
Table 3. The state of absorption of operational programs $2007-2013$

\begin{tabular}{|c|c|c|c|c|c|c|c|}
\hline \multirow[t]{2}{*}{$\begin{array}{l}\text { Operational } \\
\text { programs } \\
2007-2013\end{array}$} & \multirow[t]{2}{*}{$\begin{array}{l}\text { Allocation } \\
2007-2013\end{array}$} & \multirow{2}{*}{$\begin{array}{c}\text { Advance } \\
\text { received } \\
\text { from the EC } \\
\text { for the } \\
\text { period } 2007 \text { - } \\
2013 \\
\end{array}$} & \multicolumn{2}{|c|}{$\begin{array}{l}\text { Statements of expenditure } \\
\text { sent to the EC (current } \\
\text { absorption rate) }\end{array}$} & \multicolumn{2}{|c|}{$\begin{array}{l}\text { Repayments from the EC } \\
\text { (effective absorption rate) }\end{array}$} & \multirow{2}{*}{$\begin{array}{c}\begin{array}{c}\text { Amount of EC } \\
\text { cash received } \\
\text { (with advance) }\end{array} \\
\% \\
\end{array}$} \\
\hline & & & Valoare & $\%$ & Valoare & $\%$ & \\
\hline 0 & 1 & 2 & 3 & $4=(3 / 1) * 100$ & 5 & $6=(5 / 1) * 100$ & $7=[(2+5) / 1]^{*} 100$ \\
\hline POS CCE & 2536646054 & 229879990 & 1921495382 & 75.75 & 1498392916 & 59.07 & 68.13 \\
\hline POAT & 170237790 & 15321401 & 137529290 & 80.79 & 123801091 & 72.72 & 81.72 \\
\hline POS MEDIU & 4412470138 & 520775940 & 2735368461 & 61.99 & 2555947260 & 57.93 & 69.73 \\
\hline POR & 3966021762 & 335341959 & 2534841696 & 63.91 & 2534846902 & 63.91 & 72.37 \\
\hline POS DRU & 3476144996 & 451898849 & 1894810402 & 54.51 & 1712351257 & 49.26 & 62.26 \\
\hline POS T & 4288134778 & 525615535 & 2686323663 & 62.65 & 2620878885 & 61.12 & 73.38 \\
\hline PODCA & 208002622 & 27040341 & 187726405 & 90.25 & 170562150 & 82.00 & 95.00 \\
\hline TOTAL & 19057658140 & 2105874015 & 12098095299 & 63.48 & 11216780462 & 58.86 & 69.91 \\
\hline
\end{tabular}

Source: Ministry of European Funds; data processed by the authors

On the part of the Managing Authorities, the lack of experts was perhaps the main reason for the delay of the evaluations. Also, legislative changes, as was the case with green certificates for POSCCE, have resulted in the blocking of many projects submitted or even under implementation.

At the level of the Managing Authorities, the following causes can explain the low absorption rate: the non-stimulus pay of the administrative apparatus involved, followed by a large staff fluctuation, unclear provisions and guidelines, uncoordinated programs and projects, low efficiency of technical assistance, excessive bureaucracy, the mechanism of solving defective complaints, indefinite post monitoring and the cumbersome operation of SMIS - CNSR. From the point of view of the Beneficiaries, the low absorption rate had as cause a market of immature consultancy, poor expertise in project development, lack of private cofinancing, changes in technical solutions, contractual prerogatives in the field of public procurement. The effects of the aforementioned problems consist in the occurrence of malfunctions and delays at the stages of preparation, launch, evaluation, selection, contracting, implementation and reimbursement; financial difficulties of Managing Authorities and Beneficiaries, termination of contracts, abandonment of the projects to be implemented, systemic financial corrections, reduced project approval, European Commission's pre-payment measures.

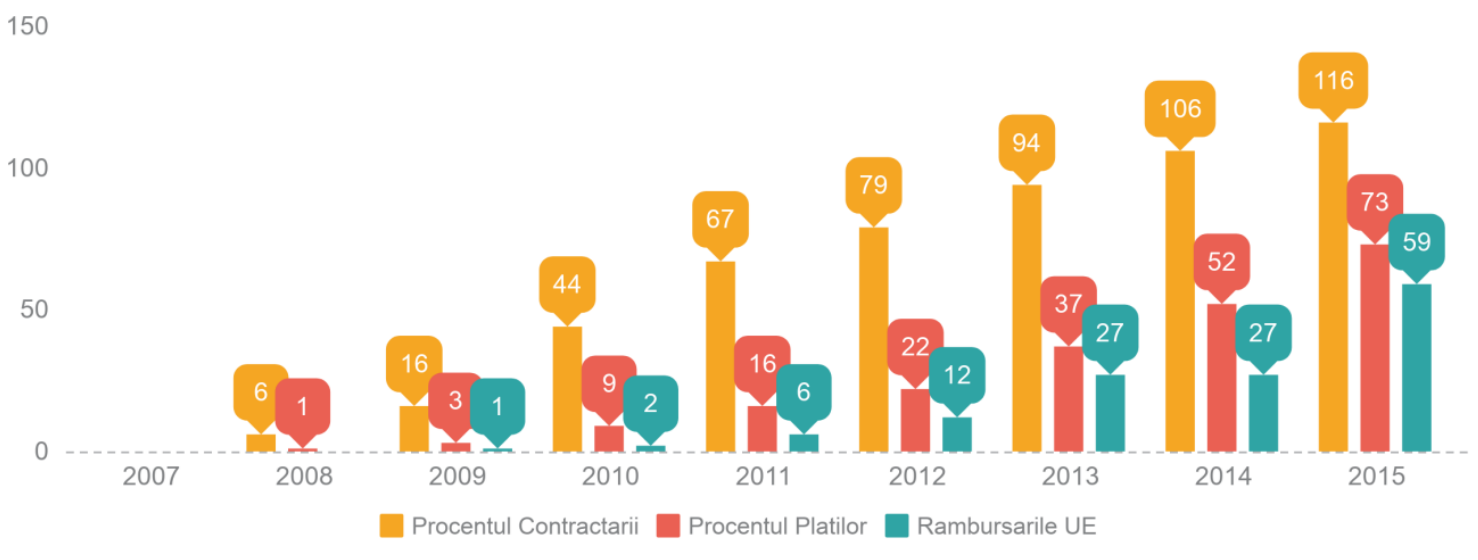

Data source: National Institute of Statistics, Ministry of European Funds; data processed by the authors

Figure 6. Implementation of the MFF 2007 - 2015 in Romania

As shown in Figure above, the evolution of absorption for the 2007-2013 programming period (2015) shows that in the first years of 2007, 2008, 2009, 2010, the amounts absorbed were insignificant, which is justified by the fact that the first two years were allocated to the programming and launch of the first call for projects. Starting in 2012, there is an increase in the European funds, reaching a $59 \%$ absorption by the 
end of 2015 (amounts actually received from the European Commission compared to the $63.31 \%$ requested by Romania). Starting from 2013, Romania has a net beneficiary position in relation to the European Union budget. The final data officially published by the Ministry of European Funds together with the Ministry of Finance indicates in February 2016 that the final absorption will amount to $78 \%$.

Among the effective measures taken by Romania since 2012, we mention the reduction of the period of analysis of requests for reimbursement from 45 days to 20 days; the allocation of funds from the state budget from privatizations for the Managing Authorities that had the programs suspended by the European Commission; introducing an alternative to the claim for reimbursement, namely the payment request for those who did not have the necessary liquidity to make payments; simplification of the procurement procedure.

At the end of 2015, indicators at headline targets were as follows: for the transport infrastructure, the rehabilitated railway was $127 \mathrm{~km}$ from the proposed $209 \mathrm{~km}$ target; the new TEN-T road infrastructure was $312 \mathrm{~km}$ to $372 \mathrm{~km}$, the rehabilitated TEN-T road infrastructure was $289 \mathrm{~km}$ to $302 \mathrm{~km}$; the rehabilitated county road infrastructure was $1667 \mathrm{~km}$ to $877 \mathrm{~km}$ and the rehabilitated road infrastructure was $198 \mathrm{~km}$ from $325 \mathrm{~km}$. In the category of environmental investments, 107 were made/rehabilitated compared to 200 treatment plants; 32 renewable energy projects compared to 30; 312 compared to 430 localities with new/ rehabilitated water systems and only 1 integrated waste management system versus 37 proposed to be achieved. For social infrastructure, 58 medical units were rehabilitated compared to $62 ; 172$ social centers versus 223; from which 47,853 people benefited from 10,000 and 93,399 persons compared to 40,000 benefited from the rehabilitated pre-university educational infrastructure. Territorial development has made 94 integrated urban development plans compared to the 30 proposed ones; 352 urban development projects versus 60 and 8,203,338 beneficiaries for PIDU projects versus 400,000 proposed. The development of Human Capital created 41,514 new jobs compared to 38,500; has trained 256,668 staff from education to the target of 75,000; has attracted 72,901 vulnerable persons in the specific programs as of 13:00 and has ensured the participation in the integrated programs of 122,017 unemployed versus 65,00 proposed. The increase in competitiveness supported 1976 micro-enterprises compared to 1500; assisted 2729 SMEs over 2000; hosted in tourism structures rehabilitated 989,300 tourists versus 400,000 and contracted 233 tourism projects versus 221.

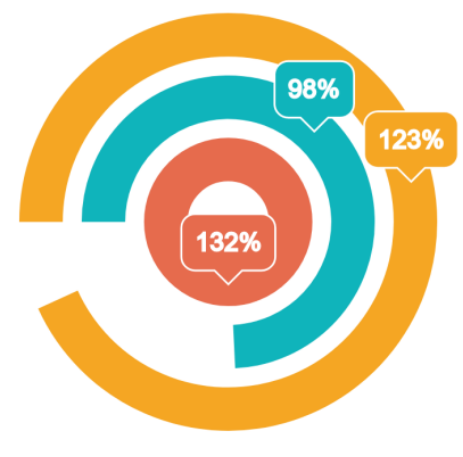

FEDR $\square$ Fondul de Coesiune $\square$ Fondul European Social

Data source: Ministry of European Funds; data processed by the authors

Figure 7. Contracting on the three types of funds in Romania 2007-2015

In terms of disbursement of European funds, all national operational programs worked well, except for the Sectoral Operational Program Human Resources Development, which at the end of 2015 had 94 million Eur in decommitment. For the year 2016, according to the new $n+3$ approved rule, the likely amount to be disbanded on the SOP Transport, SOP ENV, PO Regional, POS Competitiveness, PO Technical Assistance, SOP Human Resources Development and PO Administrative Capacity Development would be 2296 million Of euro.

European funds have made a significant contribution to the evolution of Romania's Gross Domestic Product by estimating a 10\% increase in the latter in the seven years of their actual use 2009-2015. Practically, would have used the European funds allocated to Romania after joining the European Union, at 
present Romania has benefited from the European club membership by means of a $10 \%$ increase of GDP for the European Financial Framework 2007 - 2013 (actually used between 2009 and 2015 according to the rule $n+2$ ). This contribution is visible especially after 2012, which showed an increase in GDP due to European funds of 3\%, which subsequently increases to $6.7 \%$ in 2014 and reaches 10 in 2015 . In terms of investments made in Romania in the same period (2009-2015), those made using European funds are estimated at $24 \%$ of the total national investments. Investments in major intervention areas on 31.12.2015 were as follows: transport - 30\%; average - $23 \%$; the labor market - $12 \%$; business environment - $11 \%$; research - $8 \%$; energy - $3 \%$; education - $2 \%$; administrative capacity - $2 \%$; cultural heritage - $2 \%$; technical assistance - 2\%; social infrastructure: $2 \%$; tourism - $1 \%$; health - $1 \%$; IT - $1 \%$. Also in this case, the level of investment financed by European funds has started to grow substantially from 2012 by $6.5 \%$, reaching $14.5 \%$ in 2013 and $25 \%$ in 2014 . From the point of view of jobs, estimates that the European funds allocated to Romania for the period 2007 - 2013 (2015) led to an increase of $3.8 \%$ of the population employed through the Community financial intervention. The statistical data is $1.1 \%$ in $2012,2.4 \%$ in 2013 , $3.4 \%$ in 2015 to $3.8 \%$ in 2015 . The unemployment rate declined proportionally to $-1 \%$ in $2012,2 \%$ in 2013 , 2.8 in 2014 and -3.1 in 2015 . Wages increased by $25 \%$ as a result of the use of European funds. Much of the funds were also allocated for payments under projects funded by European funds, in particular through POSDRU or OPTA. Average monthly wage increased by $2 \%$ in $2011,5 \%$ in $2012,11 \%$ in $2013,19 \%$ in 2014 and $25 \%$ in 2015 . Private consumption increased by $19 \%$ compared to the to use European funds. A more significant development has been seen since 2011 with $2 \%, 4.2 \%$ in 2012, 9.8\% in 2013, $15.2 \%$ in 2014 and $19 \%$ in 2015.

Currently, compared to the new contracting period 2014-2020, Romania has operational programs approved by the European Commission and has completed 23 ex-ante conditionalities, while another 13 are still in progress. The year 2015 was one with limited activity, as the state's efforts were directed primarily towards finalizing the best possible conditions for the MFF 2007-2013. The year 2016 marked the launch of a large number of funding calls, resulting in a steep increase in the contracting rate from nearly $0 \%$ to $10 \%$ in 2016, and will increase significantly due to the $€ 13$ billion budget allotted the Cohesion Fund. The National Rural Development Program has performed at least as well as in the previous contracting period, reaching around $20 \%$ contracting percentage and about $10 \%$ payment percent. The High Infrastructure Operational Program and the Competitiveness Operational Program contracted together about 1.4 billion Eur.

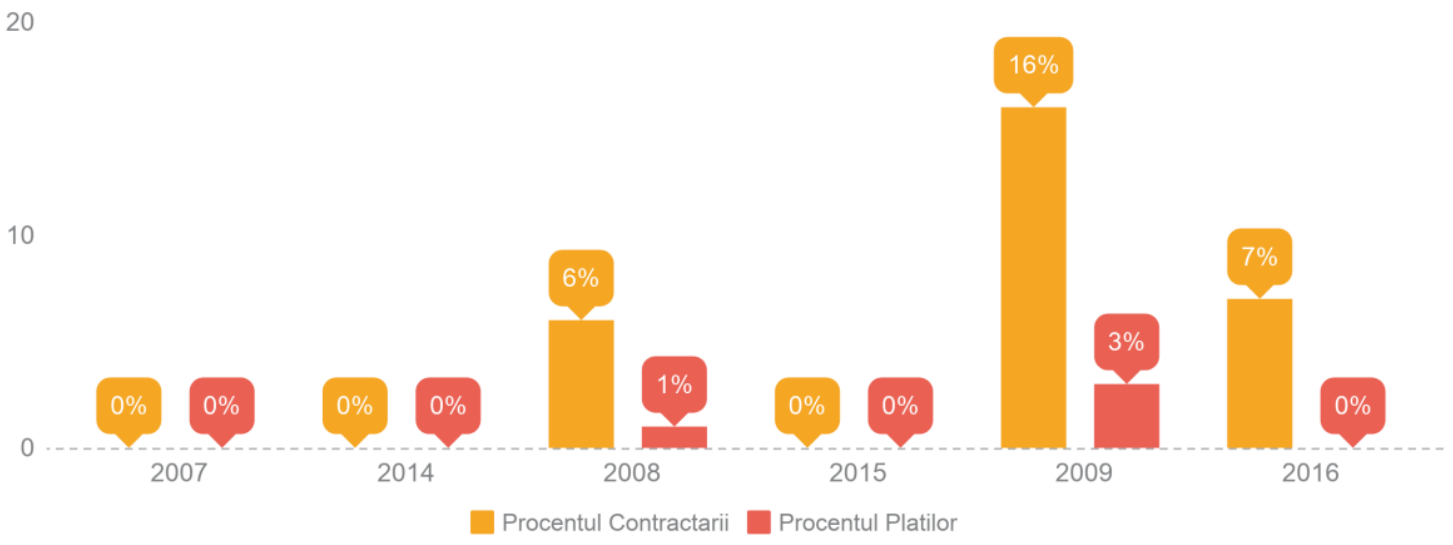

Data source: Ministry of European Funds; data processed by the authors

Figure 8. Comparison of contracting/payment percentages (2007-2009) - (2014-2016)

As can be seen from the chart above, the management of European funds performed better in the first part of the 2007-2013 Multiannual Financial Framework over the similar period of the 2014-2020 MFF. However, improvements to the IT system, reducing bureaucracy and facilitating procurement procedures should improve the absorption of European funds in the coming period. 
Table 4. The absorption stage 2014-2017

\begin{tabular}{|c|c|c|c|c|c|c|c|}
\hline \multirow[t]{2}{*}{$\begin{array}{l}\text { Programs } \\
2014-2020\end{array}$} & \multirow[t]{2}{*}{$\begin{array}{l}\text { Allocation } \\
\text { 2014-2020 }\end{array}$} & \multicolumn{2}{|c|}{$\begin{array}{c}\text { Payments to } \\
\text { beneficiaries (EU) }\end{array}$} & \multicolumn{2}{|c|}{$\begin{array}{l}\text { Amounts requested by the EC } \\
\text { within the EU allocation of OP } \\
\text { (current absorption rate) }\end{array}$} & \multicolumn{2}{|c|}{$\begin{array}{c}\text { Reimbursements from } \\
\text { EC (effective } \\
\text { absorption rate) }\end{array}$} \\
\hline & & Value & $\%$ & Value & $\%$ & Value & $\%$ \\
\hline 0 & 1 & 2 & 3 & 4 & 5 & 6 & 7 \\
\hline OP Regional & 6600000000 & 51476744 & 0.78 & 26969422 & 0.41 & 24272480 & 0.37 \\
\hline OP High Infrastructure & 9418524484 & 968827098 & 10.29 & 953653087 & 10.13 & 858287778 & 9.11 \\
\hline OP Competitiveness & 1329787234 & 146572615 & 11.02 & 86143549 & 6.48 & 59118754 & 4.45 \\
\hline OP Human Capital & 4326838744 & 25014473 & 0.58 & 3892197 & 0.09 & 0 & 0 \\
\hline $\begin{array}{l}\text { OP Administrative } \\
\text { capacity }\end{array}$ & 553191489 & 24709051 & 4.47 & 22964870 & 4.15 & 20668383 & 3.74 \\
\hline OP IIMM & 100000000 & 93090000 & 93.09 & 93090000 & 93.09 & 83781000 & 83.78 \\
\hline OP Technical Assistance & 212765958 & 49706461 & 23.36 & 49540248 & 23.28 & 44586223 & 20.96 \\
\hline Subtotal & 22541107909 & 1359396442 & 6.03 & 1236253373 & 5.48 & 1090714619 & 4.84 \\
\hline NP Rural development & 8127996402 & 2141031435 & 26.34 & 2106616091 & 25.92 & 1991025758 & 24.50 \\
\hline POPAM & 138421371 & 14892225 & 8.84 & 12237475 & 7.27 & 9785156 & 5.81 \\
\hline Totl FESI & 30837525682 & 3515320103 & 11.40 & 3355106938 & 10.88 & 3091525533 & 10.03 \\
\hline FEGA 2015-2020 & 11196040258 & 3950185560 & 35.28 & 3950185560 & 35.28 & 3282437931 & 29.32 \\
\hline
\end{tabular}

Data source: Ministry of European Funds

At the end of 2017, the European Commission sent EUR 1.09 billion reimbursements for operational programs managed by MDRAPFE and financed by European structural and investment funds (with the exception of the European Territorial Cooperation Programs), which is 4.83\%; EUR 2.5 billion represents the total amount received from the EC for the same programs, including repayments and pre-financing, equivalent to $11.07 \%$ and over 1.37 billion (6.09\%) payments to beneficiaries, of which 1,23 billion was requested by the EC via payment requests.

\section{Conclusions}

The article, based on the authors' study, concludes that the use of EU funds for project financing is an important element in aligning the Romanian economy's standard of living to European standards but also in terms of the possibility of participating in other community projects. The study shows that an important area in which top-up performance can be achieved is the efficient use of the "Multi-Annual Funding Framework" launched in 2007 by the European Union to support countries that joined after 2005 to ensure growth economic growth and thus aligns with European standards. Access to the three types of funds set up by the European Union is also important for Member States. From the study it is concluded that Romania has started this process of accessing the community funds on the basis of projects. We also refer to Romania's participation. Another conclusion that emerges from this study is that community projects are open to all member countries, but they can also include those countries that are specialized in some of the activities that are the subject of the respective projects and have possibilities for co-financing.

\section{References}

1. Akçomaka, I.S. and ter Weel, B. (2009). Social capital, innovation and growth: Evidence from Europe. European Economic Review, 53 (5), 544-567.

2. Anghel, M.G., Anghelache, C. and Dumitrescu, D. (2016). Investment funds and portfolio of loan guarantees as financial steps proposals to support innovative Small and Medium Enterprises. Theoretical and Applied Economics, XXIII (3) (608), Autumn, 119-126.

3. Anghelache, C., Anghel, M.G., Diaconu, A., Badiu, A. and Niţă, G. (2016). Modele utilizate în analiza absorbţiei fondurilor comunitare, Proceedings of the International Symposium "Romania in the European Union - Methods and Models of Macroeconomic Analysis and Prognosis", Universitatea "Artifex" din Bucureşti, 19-20 mai 2016, Editura Artifex, Bucureşti, 278-292. 
4. Berezin, M. and Diez-Medrano, J. (2008). Distance matters: Place, political legitimacy and popular support for European integration. Comparative European Politics, 6 (2), 1-32.

5. Chalmers, A.W. (2013). Trading information for access: informational lobbying strategies and interest group access to the European Union. Journal of European Public Policy, 20 (1), 39-58.

6. Dachs, B. and Pyka, A. (2010). What drives the internationalisation of innovation? Evidence from European patent data. Economics of Innovation and New Technology, 19 (1), 71-86.

7. Farole, T., Rodríguez-Pose, A. and Storper, M. (2011). Cohesion Policy in the European Union: Growth, Geography, Institutions. Journal of Common Market Studies, 49 (5), 1089-1111.

8. Goldberg, P.K. and Pavcnik, N. (2007). Distributional effects of globalization in developing countries. Journal of Economic Literature, 45 (1), 39-82.

9. Kennan, J. (2017). Open borders in the European Union and beyond: migration flows and labor market implications. National Bureau of Economic Research, Cambridge, Working Paper No 23048.

10.Lane, P.R. (2006). The real effects of european monetary union. The Journal of Economic Perspectives, 20 (4), 47-66.

11.Maggioni, M.A., Nosvelli, M. and Uberti, T.E. (2007). Space versus networks in the geography of innovation: A European analysis. Regional Science, 86 (3), 471-493.

12.Onetti, A., Zucchella, A., Jones, M.V. and McDougall-Covin, P.P. (2012). Internationalization, innovation and entrepreneurship: business models for new technology-based firms. Journal of Management \& Governance, 16 (3), 337-368.

13.Pinto, H. (2009). The Diversity of Innovation in the European Union: Mapping Latent Dimensions and Regional Profiles. European Planning Studies, 17 (2), 303-326.

14.Pulignano, V. (2009). International Cooperation, Transnational Restructuring and Virtual Networking in Europe. European Journal of Industrial Relations, 15 (2), 187-205.

15.Voigt, P. and Moncada-Paternò-Castello, P. (2012). Can Fast Growing R\&D-Intensive Smes Affect the Economic Structure of the Eu Economy?: A Projection to the Year 2020. Eurasian Business Review, 2 (2), 96-128. 